\title{
THE CONSTITUTION
}

Constitutional Revisions Are Proposed To Reflect

Two Significant Developments: Sections And Student Chapters

The Constitution of the Materials Research Society is printed here with additions (....) and deletions [.....] proposed by the Council.

\section{Article I - Name and Objective[s]}

[Section] 1. The name of this organization shall be the Materials Research Society.

[Section] 2. The objective[s] of this Society [are] (is) to serve professionals working in the field of materials science and engineering by

(a) fostering interaction between those working on different classes of inorganic and organic materials such as metals, ceramics, polymers, and electronic materials;

(b) sponsoring interdisciplinary meetings of interest to materials scientists and engineers;

(c) disseminating information relevant to the interests of the materials community.

\section{Article II - Membership}

[Section] 1. Membership in the Materials Research Society is open to all persons professionally involved in materials science and engineering.

[Section] 2. A full time undergraduate or graduate student with an expressed interest in materials science may, upon payment of Student Membership dues, be accepted as a Student Member for a period of one year. Student Membership may be renewed annually by submission of dues and recertification of student status. The rights and privileges of Student Members shall be the same as for regular members except that Student Members shall not have the right to vote or hold office on the Council.

[Section] 3. Dues and other responsibilities of membership [will] (shall) be established [in response to need] by the Council.

\section{Article III - Administration}

[Section] 1. The general administration shall be the responsibility of the officers and the Council.

[Section] 2. The officers of the organization shall be a President, a First Vice President, who is also the President Elect, a Second Vice President, a Secretary, [and] a Treasurer[.] (, and the immediate Past President.) The Executive Committee [will] (shall) consist of the officers of the Society.

[Section] 3. The Council shall be composed of the officers [, the immediate Past President,] and fifteen (15) Councillors elected from the Society. The Meeting Chairpersons shall be nonvoting members of the Council.
[Section] 4. The term of office of the President, the First Vice-President, and the Second Vice-President shall be one year. The terms of office of the Secretary and Treasurer shall be two years. The term of office of Councillors shall be three years. No Councillor shall normally serve more than two consecutive (full) terms.

\section{Article IV - Responsibilities of Officers and Council}

[Section] 1. The President shall be the chairman of the Executive Committee and the Council, shall make appointments to committees, and generally act as the representative for the Society.

[Section] 2. The First Vice-President shall act for the President on any occasion when the latter is unable to carry on his normal duties and shall assume the office of President at the conclusion of the term of the President, or before if the office of the President becomes permanently vacant. The First and Second Vice-Presidents (and the immediate Past President) shall assist the President in the business of the Society.

[Section] 3. The Secretary shall keep the minutes of all Council and Executive Committee meetings, maintain the records of the Society, conduct the business of the election and carry on all correspondence for the Society as directed by the President or the Council.

[Section] 4. The Treasurer shall act as custodian of all funds received by the the Society, shall maintain financial records for the Society and shall make disbursements as directed by the President or the Council. The Treasurer shall provide financial reports at the Council meetings and otherwise as requested by the President and shall perform such additional duties as are assigned by the President.

[Section] 5. The Council shall have the responsibility for the direction of all affairs and activities of the Society. Council meetings shall be called by the President by notifying all Council members and providing an agenda at least two weeks in advance. A quorum for a Council meeting shall consist of seven voting members of the Council including at least two members of the Executive Committee.

\section{Article V - Meetings and Conferences}

[Section] 1. The Society shall sponsor conferences concerning subjects of interest to its members.

[Section] 2. The conferences to be sponsored may originate within the Society or be brought to the Society for sponsorship by outside groups.

[Section] 3. Conferences of the Society shall be organized and overseen by the Program Committee 
appointed by the President. The Committee shall include two members of the Council.

[Section] 4. Conferences jointly sponsored shall include two members of the Council, or their delegates, on the organizing committee.

[Section] 5. The Society shall disseminate technical information to its members and to the general materials community through a broad range of publication formats. Special issues of existing journals or monographs may be used to report the proceedings of its conferences. The Society [can] (may) establish official journals.

\section{Article VI - Finances}

[Section] 1. The annual dues shall be payable in advance, the amount to be determined by the Council. The dues shall be applied to the costs of the communications and the administration of the Society. [Section] 2. The organizational committee of a conference shall ensure its financial support by the establishment of suitable registration fees and solicitation of institutional support. Financial obligations shall be approved by the Council.

[Section] 3. The records and an annual financial report of the Treasurer shall be examined each year by the Finance Committee, which shall arrange an annual audit.

[Section] 4. In the event of dissolution, disposal of funds shall be decided by the Council. Such funds are to be used only for the advancement of the purposes of the organization.

\section{Article VII - Amendments}

[Section] 1. Amendments to the Constitution may be proposed by the Council [for ratification by the membership] (and shall be submitted to the members for ratification).

[Section] 2. Amendments may be proposed to the Council by any fifteen (15) members. The council shall indicate whether it approves or disapproves, but in either case the amendments shall be submitted to the members for ratification.

[Section] 3. [The] (An) amendment is accepted if ratified by two-thirds of those members voting on it.

\section{Article VIII - Bylaws}

[Section] 1. The Council shall enact, by a majority vote, regulations or Bylaws to administer the Society.

[Section] 2. Amendments to the Bylaws shall be made by the Council and the membership notified. Any fifteen (15) members may petition the Council for a referendum on any such amendment or other action of the Council; such a referendum shall be submitted to the membership by mail ballot and must be approved by two-thirds of those voting on it.

\section{Article IX - Parliamentary Authority (and/or Procedure)}

[Section] 1. Should questions [or] (of) parliamentary authority (and/or procedure) arise, Roberts' Rules of
Order shall be followed.

\section{(Article X - Sections)}

(1. A section may be established to provide local forums for the interaction of scientists and engineers in various materials disciplines, and to promote the exchange and dissemination of information from the society. Establishment of a section, with a title depicting the region with which it is associated, will be authorized by the council.)

\section{(Article XI - Student Chapters)}

(1. Student Chapters may be established to foster discussion among students and faculty in the various materials disciplines, to generate student interest in materials science, and to promote the exchange and dissemination of information from the Society. A Chapter, with a title containing the name of the college or university with which it is associated, will be authorized by the Council.)

\section{FOURTH ION-BEAM CONFERENCE}

The Fourth International Conference on Ion Beam Modification of Materials was held at Cornell July 16-20, and was attended by some 380 participants from the United States, Europe, Asia, and Australia. Topics ranged from ion implantation in metals and semiconductors to reactive ion etching and formation of fine line structures with ion beams. Organizer of the meeting (and recipient of the MRS's Von Hippel Award), Professor J.W. Mayer of Cornell, reports:

\section{Ion Beam Interaction}

"The emphasis of the conference was on physical processes and the materials science aspects of the interaction of ion beams with solids. In addition, there were oral presentations and posters on the applications of implantation to metallurgical problems of wear and corrosion, as well as to semiconductor structures.

"The conference opened with an analysis of New York State wines in the Johnson Art Museum overlooking Cayuga Lake and closed with the banquet address by Millie Dresselhaus on 'Education, Technology, and International Programs.' There were laboratory tours of the National Submicron Facility, the Cornell High Energy Synchrotron Source (CHESS), and the Rutherford Backscattering Facility."

\section{The Conference Series}

The conference series started in 1970 as "Ion Implantation in Semiconductors," chaired by Fred Eisen, and evolved to "Ion Beam Modification of Materials" in 1978, chaired by Jozsef Gyulai, in order to reflect the increased interest in the use of ion beams in the processing of metals, polymers, and ceramics. 